\title{
REPOSITORY OF IMAGES FOR REVERSE ENGINEERING AND MEDICAL SIMULATION PURPOSES
}

\section{REPOZYTORIUM OBRAZÓW NA POTRZEBY INŻYNIERII ODWROTNEJ I SYMULACJI MEDYCZNEJ}

\author{
${ }^{1}$ Institute of Mechanics and Applied Computer Science, Kazimierz Wielki University in Bydgoszcz, Poland \\ ${ }^{2}$ Department of Physiotherapy, Ludwik Rydygier Collegium Medicum in Bydgoszcz, \\ Nicolaus Copernicus University in Toruń, Poland \\ ${ }^{3}$ Neurocognitive Laboratory, Centre for Modern Interdisciplinary Technologies, \\ Nicolaus Copernicus University in Toruń, Poland \\ ${ }^{4}$ Department of Biochemistry, Ludwik Rydygier Collegium Medicum in Bydgoszcz, \\ Nicolaus Copernicus University in Toruń, Poland
}

\section{S u m mary}

Novel technologies such as 3D printing (additive manufacturing), 3D scanning and reverse engineering may significantly improve application of the principles of medicine in current clinical practice. This paper aims at presentation of the own concept of the repository of medical images based on 3D printing and reverse engineering technology. The proposed concept of the repository can constitute a beginning of the novel family of commercial techniques needed for development and optimization of reverse engineering toward printing the fully clinically functional solutions.

\section{Streszczenie}

Nowe technologie, takie jak druk 3D, skanowanie 3D czy inżynieria odwrotna, mogą znacząco poprawić stosowanie reguł medycyny w obecnej praktyce klinicznej. Artykuł prezentuje własną koncepcję repozytorium obrazów medycznych w oparciu o technologie druku 3D i inżynierii odwrotnej. Proponowana koncepcja może stanowić początek nowej rodziny technik komercyjnych potrzebnych do rozwoju i optymalizacji inżynierii odwrotnej w kierunku drukowanie rozwiązań w pełni funkcjonalnych klinicznie.

Key words: 3D printing, reverse engineering, medical imaging, repository, artificial tissue, assistive technology

Stowa kluczowe: druk 3D, inżynieria odwrotna, diagnostyka obrazowa, repozytorium, sztuczna tkanka, technologia INTRODUCTION wspomagająca

Medical sciences and health sciences are open to novel approaches and technologies. Many advances in health care have been achieved as a result of application of novel technologies (especially in the area of medical IT, medical robotics, material engineering, etc.).
Traditional manual design and manufacturing have severe limitations, especially concerning possibility of quick preparation of production, pace of its modification, and personalization of products. Novel technologies such as 3D printing (additive manufacturing), 3D scanning and reverse engineering 
may significantly improve application of the principles of medicine in current clinical practice. Although aforementioned novel technologies are regarded as supplementary, they can avoid the limitations or fill the gap within existing biomedical technologies and methods. This way efficiency of the current therapeutic methods may increase, costs can be lowered, hospitalization can be shortened, and patient's healthrelated quality of life can be increased.

This paper aims at presentation of the own concept of the repository of medical images based on 3D printing and reverse engineering technology.

\section{D PRINTING}

Additive manufacturing (3D printing) can use various materials (plastic, metal, ceramics, living cells) in layers to produce a 3D object using diverse technologies. Product is built vertically, layer by layer, allowing creation of the complex structures, even not produced using more traditional technologies. Printing features (speed, quality, geometric accuracy, shape reconfiguration possibilities, etc.) and used materials depend on the selected technology. Access to the cheaper commercial technologies, computer-aided design (CAD), rapid prototyping (RP), and computeraided manufacturing (CAM) significantly influenced development of physical models and final products printed directly from 3D computer data sets. Medical applications of aforementioned technologies cover following areas:

- learning and medical simulation,

- scientific research, modelling and testing of bones, soft tissues, assistive technology, etc.

- diagnostics based on 2D images converted to 3D,

- fast face/head scanning and fast whole body scanning,

- 3D-printed artifacts used in (neuro)surgery, drug fabrication, and rehabilitation engineering, etc.

- bioprinting of tissues and organs,

- customization of products to meet individual patient's requirements.

\section{REVERSE ENGINEERING}

Reverse engineering is based on digitizing real objects, such as body parts, usually for replication or modification (e.g. individualization) purposes. Some digital files representing $3 \mathrm{D}$ objects may be reconstituted from other sources, including series of medical images. Quality of the copy usually depends on the quality of the images, applied software, and resolution of $3 \mathrm{D}$ printing.

There is an assumption that each $3 \mathrm{D}$ copy reflects the same original (or modified by therapists/manufacturer) data, i.e. is the same as original, but may be produced from the pother material. Moreover, there is lack of plastic molds or wraps needed during the process of fabrication. From the medical point of view: modification of geometry and material properties of the 3D-printed model is possible on many stages of the additive manufacturing. Some additional copies (e.g. for control purposes) are possible.

\section{LEARNING AND MEDICAL SIMULATION}

Practitioners recognize a need for improved instructional platforms to improve procedural individual skills and team co-operation. Quick and efficient diagnosis, therapy, rehabilitation and care still constitute a huge challenge. Advanced technologies and therapeutic methods need more specialized medical staff to achieve therapeutic success and avoid misunderstandings. Garbayo and Stahl named medical simulation 'ethical imperative in health care' decreasing learning costs to human health and quality of life [1]. Knowledge implementation is currently perceived as the best form of individual and team skills assessment, including lifelong learning of medical professionals at the undergraduate level [2, 3]. Customized 3D-printed anatomical models designed for individual and team training are regarded as very useful.

We are aware that quick development of relatively cheap and easy 3D printing in learning and medical simulation is hard to overestimate. Its potential is growing each year due both development of health sciences and technical advancement of additive manufacturing devices and materials.

Printed organs/tissues may provide surrogates for learning and medical simulation purposes, including preparation to the rare or complicated interventions. It may reduce risk in cases with limited opportunity for operating room experience. General approach within the described area constitute 3D printed personalized brain models. They can be useful for preoperative planning and neurosurgical training purposes. Ploch et al. showed advantages of the aforementioned approach: 
- use of the commonly used medical images, e.g. magnetic resonance images,

- physiologically, anatomically, and tactilely realistic (even personalized) models,

- combined various technologies: 3D printing, molding, and casting,

- easy production,

- low cost-efficiency ratio,

- high durability,

- models may be made even from soft gelatin, thus they can be softer than conventionally printed 3D models,

- total cost of the personalized brain model: approx. 50 USD,

- duration of fabrication: 24 hours [4]

a)

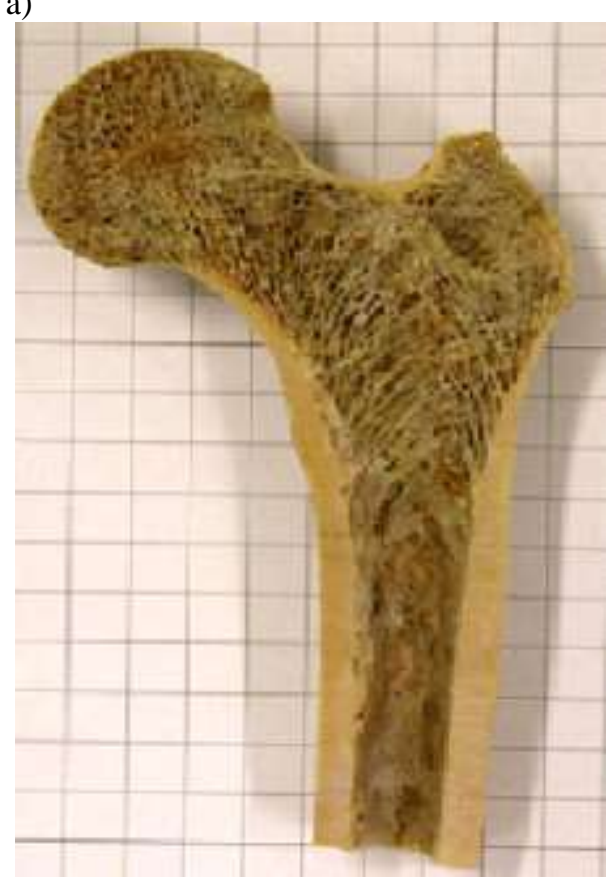

c)

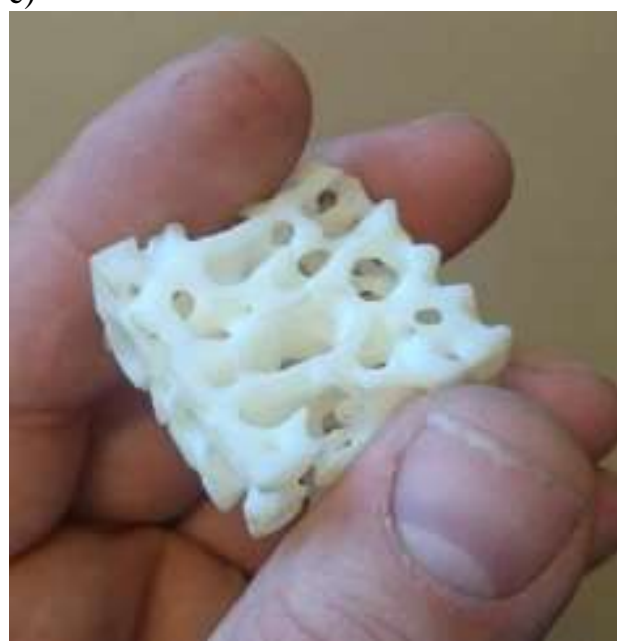

The main disadvantage of the aforementioned approach is regarded inability to produce ultrasoft materials like human brain tissue. But we are aware that direct brain printing using bio-ink is beyond our possibilities so far.

Another, more detailed approach is neurysm clipping simulator which may significantly improve learning experience in young surgeons, increasing their adaptability to new patient geometric features [5]. 3D-printed realistic pediatric pyeloplasty simulator for laparoscopic training and skills acquisition has been recently developed [6]. Consistency, hardness, elasticity of the models are close to the real tissue/organ in a particular patient [7-10]. b)

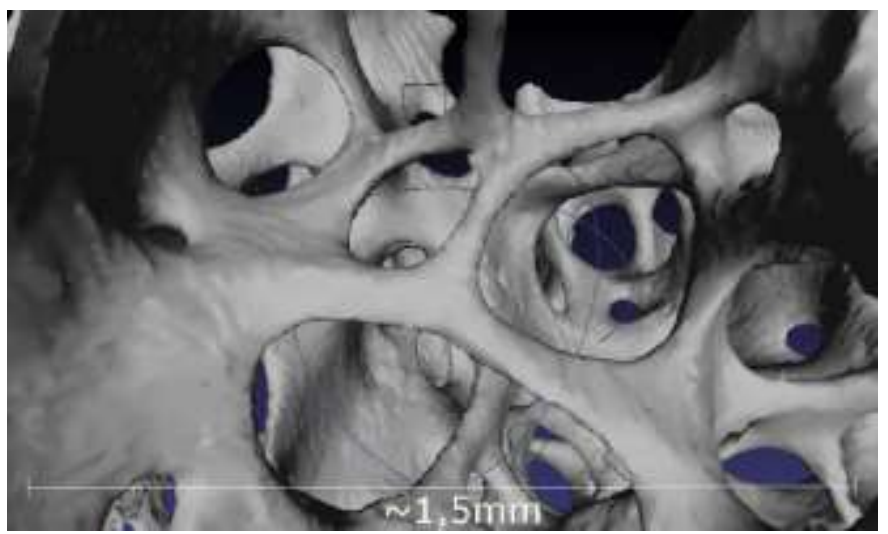

d)

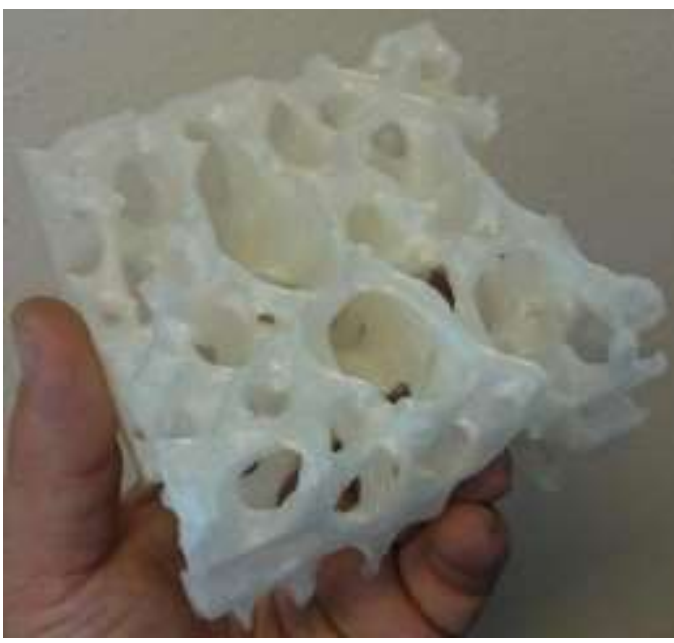

Fig 1. Example of application of the reverse engineering: a) bone, b) its digital visualization, c) its 3D-prints in various scales 


\section{THERAPY AND REHABILITATION}

Combining various therapeutic methods and techniques with reverse engineering can shorten track between diagnosis/measurements in a particular patient and ready-to-use personalized equipment or even 3Dprinted tissue. Further development of 3D printing technologies and reverse engineering in the field of orthopedic, plastic surgery, vascular surgery, neurosurgery and rehabilitation can be explosive. Their potential in the field of current and future everyday clinical practice remains underexplored.

Main topics of the papers concerning 3D printing and reverse engineering in the medicine cover training and patient education, surgical planning, upper extremity prosthetics, bones and breast reconstruction, nose, ear and cartilage reconstruction, and skin grafts [11]. High-strength structures with built-in microchannels are available [12]. Nervous system degeneration shapes the limits in such body enhancement.

\section{TOWARD PERSONALIZED REGENERATIVE MEDICINE}

Combination of materials, cells, growth factors, and novel devices can change lifesaving, therapy, rehabilitation and care, as far as change quality of life in patients living with grafts is concerned. Reverse engineering can provide quicker recovery (e.g. thanks to improved vascular features), replenishment or even replacement of damaged (or even lacking due to lifesaving amputation) tissues/organs. Current gap between transplantation needs and tissues/organs shortages can be overcome thanks to a quicker access to cost-effective artificial tissues and organs. Current research are focused on:

- semi-automated flexible production without postfabrication procedure,

- precise geometric features (including e.g. vessels), (bio)mechanical properties, structure, and function the same as the original organ in particular patient,

- retained genotype and phenotype,

- direct bioprinting of complex tissue networks,

- high cell viability, minimal stresses and forces: cells should not be harmed during printing,

- anti-allergenic features, minimal change of features in time,

- minimalized adverse effects,
- minimalized risk of graft rejection - built-in preprogrammed biocompatibility and biodegradability.

Printed organs/tissues may provide exact living replicas of the natural tissues/organs of the particular patient or even their improved (e.g. without osteoporosis in elderly people) versions:

- bones with their complete porous structure, - complex soft tissues and selected organs [13-15].

Three-dimensional printing of tissue is possible using sequential layers of cells placed on previously printed successive layers. Key factors are:

- automated and computer controlled technology,

- use of cell libraries and cellular assemblies,

- stable, functional protein arrays,

- size of cells,

- thickness of the gel,

- dispensing and positioning proteins or cells (similar as ink),

- aggregation of the closely-placed cells $[13,14,16]$.

Basic technologies are:

- laser guidance direct write (LGDW),

- modified laser-induced forward transfer techniques (LIFT)

- modified ink jet printers,

- electrohydrodynamic jetting (EHDJ) [17].

Simultaneous printing of cells and proteins, capillaries and vessels within 3-D hydrogel structures is also available [7]. Even direct neural tissue printing is available in a $3 \mathrm{D}$ multilayered collagen gel offering new possibilities for neural tissue regeneration [18]. Koch et al. printed fibroblasts and keratinocytes embedded in collagen [19], and Zhang et al. printed human umbilical vein smooth muscle cells [20]. Mannoor et al. showed bionic ear - next step toward integration of 3D printed biological tissues with functional electronic devices [21].

\section{OWN CONCEPTS AND RESEARCH}

We develop own digital library (repository) of particular human 'spare parts', primarily bones, starting from bones of spine. Such beginning is caused by our experience in development, assessment and computer modelling of the complex porous structures, including bones. Our repository can be regarded as equivalent of the digital anatomical atlases, but enhanced by simplified and automated technology of reverse engineering accessible for non-engineers (e.g. students of Bydgoszcz universities). Our preprogrammed models will be available in natural- or 
large-scale. Thus, they can be used for learning purposes. It may be emphasized by possibility of printing colored parts allowing for easier recognition of particular bones or pathological changes. Access to physiological and pathological files can provide various models depending of the disease, its stage, age of the patient, and associated deformations. Our first experiences cover also 3D-printing of the patienttailored orthopedic equipment, including orthoses and special wheelchair pads for patients with hip heterotopic ossifications.

We hope basic version of our repository will be open-source at least for Bydgoszcz universities and hospitals. The most advanced version of our repository will allow independent production of 3D models based on uploaded medical images (of the particular patient) and patterns downloaded from the repository. We hope relatively inexpensive software and hardware, and user-friendly technology will help medical specialists to become familiar with such advanced technology, and will be accompanied by significant outcomes in learning, research, and everyday clinical practice.

We possess knowledge and experience concerning both $3 \mathrm{D}$ printing and reverse engineering as far as applied informatics, biocybernetics, bioinformatics, experimental biomechanics. We also possess basic equipment including software hardware, 3D scanners, and 3D printers. Number of gathered medical images and studies is limited but still increases.

Audience may be wide. Foreign study by Jones et al. showed that opinion concerning usefulness of the $3 \mathrm{D}$ printed models is common among medical staff (95.8\%, but $82.6 \%$ required price of such model lower than 500 USD) [22].

Repositories of medical images have become more popular recently. Neuroimaging Informatics Tools and Resources Clearinghouse (NITRC) hosts fourteen projects and joins initiatives aiming at disseminate technologies of neuroimaging tools and data bases [23]. Neuro Bureau ADHD-200 Preprocessed repository constitutes huge public resource of preprocessed resting-state fMRI and structural MRI data concerning biomarkers of attentiondeficit/hyperactivity disorder [24]. Polish efforts are coordinated by the Ministry of Health. Aforementioned initiatives are stimulated by relatively novel science: connectomics, emphasizing brain's functional organization for better understanding of neural mechanisms of normal cognition and disease [25, 26].

\section{CHALLENGES AND LIMITATIONS}

Main limitations of the aforementioned own concept are:

- initial stage of research and development,

- several years need for full introduction,

- limited application of basic scientific system for everyday use by non-engineers,

- relatively high initial costs of the system dedicated purely for educational and clinical purposes,

- need for many studies: quality assessment, randomized controlled trials, compartmental studies with concurrent approaches, and clinical guidelines,

- unification, standardization, automation, for patients' safety purposes,

- social awareness among medical staff and patients.

Aforementioned limitations can be overcome by common cooperation of several universities and hospitals, and expected lower of 3D printing solutions and better cost-effectiveness of the proposed solutions.

Another limitation is a few research and publications. Evidence-based medicine (EBM) paradigm requires strong results of relevant research and confirmed results of clinical applications (including indications, contraindications, and secondary changes) in the particular case(s) to assess technology or method as efficient and safe.

Precision of 3D printing (including 3D bioprinting) is limited from millimeters to micrometers depending on technology. In the case of need for extraordinary precision there is a need for careful selection of the appropriate printing technology. No doubt development of the technology may cause an increase in the area of precision of products (including tissues and organs) printed from diverse materials, even mixed (e.g. neuroprostheses printed simultaneously form biocells, metal and plastic parts). Interaction between cells (bio-ink) and the biomaterials (e.g. scaffold) should be also cerafully studied [27,28].

Process of tissue self-assembly and extracellular matrix deposition is still a basic technological problem within bioprinting. Vascularized organs may be developed, but rather simpler (skin, cartilage, bladder). More complex organs such as heart, kidney or liver are beyond our reach now [29].

Limitation of the bioprinting is natural: printing from living cells has to be done in room temperature to avoid cells damages. We are aware that many materials may not cover this requirement. Moreover, there is a limited number of 3D printable biomaterials; thus, 
physical, chemical, and/or biological features of the original tissues/organs may not be fully reflected. Biphasic or triphasic tissues are available depending on requirements [30].

There is a limited number of novel medical materials for 3D printing (e.g. in anti-allergenic, waterresistant, non-fragile, etc.). Selection of the appropriate materials in particular case may constitute a big challenge: some materials such as wood, leather, and certain metals may be hard to use and should be replaced [31].

\section{DIRECTION FOR FURTHER RESEARCH}

Current concept of 3D repository offers many possibilities for both scientists and clinicians. It may prepare next step toward on-demand individualized biological tissues/organs. Ability of quick modification of the compounds needed for a particular patient and their just-in-time production may be regarded as key for future medical staff. Directions of further research are:

- awareness, preparation and learning of medical staff,

- new models of co-operation within multidisciplinary therapeutic team,

- testing diverse technologies and shaping their properties useful in everyday clinical practice,

- testing materials for 3D-printing (including bioprinting), indications and contraindications for application, possible adverse effects,

- vascularization of the tissues, fluid diffusion, innervation of implants,

- regeneration/replacement of the most complex tissues/organs,

- cheap, accessible, cost-efficient commercial solutions,

- specific therapy, rehabilitation and care guidelines in patients with various of 3D printed implants,

- legal and ethical issues [32-34].

\section{CONCLUSIONS}

Reverse engineering is an innovation transforming the clinical practice in the area of both printed artificial organs and patient-tailored assistive technology. Proposed concept of the repository constitutes the beginning of the novel family of commercial techniques needed for development and optimization of reverse engineering technologies toward printing the fully clinically functional solutions.

\section{REFERENCES}

1. Garbayo L., Stahl J. Simulation as an ethical imperative and epistemic responsibility for the implementation of medical guidelines in health care. Med Health Care Philos. 2016; DOI: 10.1007/s11019-016-9719-0.

2. Abas T., Juma F.Z. Benefits of simulation training in medical education. Adv Med Educ Pract. 2016;7:399-400

3. Koh J., Dubrowski A. Merging problem-based learning with simulation-based learning in the medical undergraduate curriculum: The PAIRED framework for enhancing lifelong learning. Cureus. 2016;8(6):e647.

4. Ploch C.C., Mansi C.S., Jayamohan J., Kuhl E. Using 3D printing to create personalized brain models for neurosurgical training and preoperative planning. World Neurosurg. 2016;90:668-74.

5. Ryan J.R., Almefty KK, Nakaji P., Frakes D.H. Cerebral aneurysm clipping surgery simulation using patientspecific 3D printing and silicone casting. World Neurosurg. 2016;88:175-81.

6. Cheung C.L., Looi T., Lendvay T.S., Drake J.M., Farhat W.A. Use of 3-dimensional printing technology and silicone modeling in surgical simulation: development and face validation in pediatric laparoscopic pyeloplasty. J Surg Educ. 2014;71(5):762-7.

7. Ballyns J.J., Gleghorn J.P., Niebrzydowski V., et al. Image-guided tissue engineering of anatomically shaped implants via MRI and micro-CT using injection molding. Tissue Eng Part A. 2008;14(7):1195-202.

8. Bezgin G., Reid A.T., Schubert D., Kötter R. Matching spatial with ontological brain regions using Java tools for visualization, database access, and integrated data analysis. Neuroinformatics. 2009;7(1):7-22.

9. Radenkovic D., Solouk A., Seifalian A. Personalized development of human organs using 3D printing technology. Med Hypotheses. 2016;87:30-3.

10. Niebuhr N.I., Johnen W., Güldaglar T., Runz A., Echner G., Mann P., Möhler C., Pfaffenberger A., Jäkel O., Greilich S. Technical Note: Radiological properties of tissue surrogates used in a multimodality deformable pelvic phantom for MR-guided radiotherapy. Med Phys. 2016;43(2):908.

11. Bauermeister A.J., Zuriarrain A., Newman M.I. ThreeDimensional Printing in Plastic and Reconstructive Surgery: A Systematic Review. Ann Plast Surg. 2015; DOI: 10.1097/SAP.0000000000000671

12. Gao Q., He Y., Fu J.Z., Liu A., Ma L. Coaxial nozzleassisted 3D bioprinting with built-in microchannels for nutrients delivery. Biomaterials. 2015;61:203-15.

13. Boland T., Mironov V., Gutowska A., Roth E.A., Markwald R.R. Cell and organ printing 2: fusion of cell aggregates in three-dimensional gels. Anat Rec A Discov Mol Cell Evol Biol. 2003;272(2):497-502.

14. Markwald R. Desktop organ printing. Anat Rec B New Anat. 2003;273(1):120-1.

15. Boland T., Xu T., Damon B., Cui X. Application of inkjet printing to tissue engineering. Biotechnol $\mathrm{J}$. 2006;1(9):910-7. 
16. Wilson W.C. Jr, Boland T. Cell and organ printing 1: protein and cell printers. Anat Rec A Discov Mol Cell Evol Biol. 2003;272(2):491-6.

17. Ringeisen B.R., Othon C.M., Barron J.A., Young D., Spargo B.J. Jet-based methods to print living cells. Biotechnol J. 2006;1(9):930-48.

18. Kundu J., Shim J.H., Jang J., Kim S.W., Cho D.W. An additive manufacturing-based PCL-alginate-chondrocyte bioprinted scaffold for cartilage tissue engineering. J Tissue Eng Regen Med. 2015;9(11):1286-97.

19. Koch L., Deiwick A., Schlie S., et al. Skin tissue generation by laser cell printing. Biotechnol Bioeng. 2012;109(7):1855-63.

20. Zhang Y., Yu Y., Akkouch A., Dababneh A., Dolati F., Ozbolat I.T. In Vitro Study of Directly Bioprinted Perfusable Vasculature Conduits. Biomater Sci. 2015;3(1):134-43.

21. Mannoor M.S., Jiang Z., James T., et al. 3D printed bionic ears. Nano Lett. 2013;13(6):2634-9.

22. Jones D.B., Sung R., Weinberg C., Korelitz T., Andrews R. Three-Dimensional Modeling May Improve Surgical Education and Clinical Practice. Surg Innov. 2015; 29. pii: 1553350615607641.

23. Kennedy D.N., Haselgrove C., Riehl J., Preuss N., Buccigrossi R. The NITRC image repository. Neuroimage. 2016;124:1069-73.

24. Bellec P., Chu C., Chouinard-Decorte F., Benhajali Y, Margulies D.S., Craddock R.C. The Neuro Bureau ADHD-200 Preprocessed repository. Neuroimage. 2016; DOI: 10.1016/j.neuroimage.2016.06.034.

25. Matthews P.M., Hampshire A. Clinical Concepts Emerging from fMRI Functional Connectomics. Neuron. 2016;91(3):511-28.

26. Mevel K., Fransson P. The functional brain connectome of the child and autism spectrum disorders. Acta Paediatr. 2016; DOI: 10.1111/apa.13484.

27. Steffens D, Alvarenga Rezende R, et al. 3D-printed PCL scaffolds for the cultivation of mesenchymal stem cells. J Appl Biomater Funct Mater. 2015; doi: $10.5301 / \mathrm{jabfm} .5000252$.
28. Jakus AE, Rutz AL, Shah RN. Advancing the field of 3D biomaterial printing. Biomed Mater. 2016;11(1):014102.

29. Ko H.C., Milthorpe B.K., McFarland C.D. Engineering thick tissues - the vascularisation problem. Eur Cell Mater. 2007;14:1-18; discussion 18-9.

30. Gao G, Cui X. Three-dimensional bioprinting in tissue engineering and regenerative medicine. Biotechnol Lett. 2015; 38(2):203-11.

31. Hoy M.B. 3D printing: making things at the library. Med Ref Serv Q. 2013;32(1):94-9

32. Lee W., Pinckney J., Lee V., et al. Three-dimensional bioprinting of rat embryonic neural cells. Neuroreport. 2009;20(8):798-803.

33. Rankin T.M., Giovinco N.A., Cucher D.J., Watts G., Hurwitz B., Armstrong D.G. Three-dimensional printing surgical instruments: are we there yet? J Surg Res. 2014 Jun 15;189(2):193-7.

34. Yoo S.S. 3D-printed biological organs: medical potential and patenting opportunity. Expert Opin Ther Pat. 2015;25(5):507-11.

Address for correspondence:

dr Emilia Mikołajewska

Department of Physiotherapy

Ludwik Rydygier Collegium Medicum

Nicolaus Copernicus University

ul. Jagiellońska 13-15

85-094 Bydgoszcz

Poland

e-mail: e.mikolajewska@wp.pl, emiliam@cm.umk.pl

Received: 20.07.2016

Accepted for publication: 12.08.2016 